\title{
The Chemical Pregnancy
}

\author{
MIHAI CRISTIAN DUMITRASCU1,2, MADALINA ILIESCU ${ }^{3}$, RAZVAN COSMIN PETCA ${ }^{1,4 *}$, FLORICA SANDRU 1,3*, \\ CLAUDIA MEHEDINTU ${ }^{1,5}$, PATRICIA DELIA FARCASANU ${ }^{1}$, NICOLETA MARU ${ }^{1}$, CALIN CHIBELEAN ${ }^{6}$, AIDA PETCA ${ }^{1,3}$ \\ ${ }^{1}$ Carol Davila University of Medicine and Pharmacy, 8 Eroii Sanitari Bvd., 050474, Bucharest, Romania \\ 2University Emergency Hospital, Splaiul Independentei no.169, 050098, Bucharest, Romania \\ ${ }^{3}$ Elias Emergency Hospital, 17 Marasti Blvd., 011461, Bucharest, Romania \\ 4Prof. Th. Burghele Clinical Hospital, 20 Panduri Str., 050653, Bucharest, Romania \\ ${ }^{5}$ Malaxa Clinical Hospital, 12 Vergului Str., 022441, Bucharest, Romania \\ ${ }^{6}$ George Emil Palade University of Medicine, Pharmacy, Science and Technology of Targu Mures, 38 Gheorghe Marinescu Str., \\ 540139, Targu Mures, Romania
}

\begin{abstract}
The chemical pregnancy is an early pregnancy loss occurring shortly after implantation. $50-75 \%$ of all miscarriages are considered to be chemical pregnancies. Although the pregnancy test is positive, the fetus cannot be detected on ultrasounds; it can be asymptomatic or it can have menstrual-like cramping and bleeding. There are numerous risk factors associated with miscarriage, such as: epidemiological, genetic, anatomical, endometrial, endocrine and immune factors, infections, inherited thrombophilia and antiphospholipid syndrome. Many drugs are related with spontaneous miscarriage, significant evidence being found for nonsteroidal anti-inflammatory drugs, inhaled corticosteroids, antidepressant medication, antiepileptic and antihypertensive drugs, the artemisinin-based combination therapy and for the diclofenac/ misoprostol combination. Besides the common diseases like asthma, chronic hypertension, chronic kidney disease, thyroid disorders, diabetes mellitus, polycystic ovary syndrome and rheumatoid arthritis, there was also found a higher correlation with the risk of miscarriage for the Zika Virus infection. In conclusion, chemical pregnancy is a type of early pregnancy loss which usually doesn't need prevention, associated with multiple risk factors.
\end{abstract}

Keywords: miscarriage, risk factor, early pregnancy loss, exposure, environmental factors

A chemical pregnancy is defined as an early pregnancy loss occurring shortly after implantation. It differs from other miscarriages by the fact that these types of pregnancy loss can occur at any time during a pregnancy, but more frequently before the $6^{\text {th }}$ week. Although there are found high levels of human chorionic gonadotropin in the patient's blood, the fetus can not be detected on ultrasounds. Chemical pregnancies account for $50-75 \%$ of all miscarriages [1,2].

Although the exact cause of a chemical pregnancy remains unknown, there are described some contributing factors, such as: advanced maternal age, low body mass index (BMI), uterine abnormalities, insufficient hormone levels (progesterone), chromosomal abnormalities, infections, implantation outside the uterus, thyroid disorders $[1,2]$.

A chemical pregnancy is usually indicated by a positive pregnancy test, followed by a negative one. Studies showed that up to $25 \%$ of pregnancies result in miscarriage before a woman misses a period or has any pregnancy symptoms. Sometimes, a chemical pregnancy can be asymptomatic, but it can also be suggested by mild abdominal cramping, mild spotting a week before an expected period, vaginal bleeding within days of getting a positive pregnancy result. These symptoms can also occur during a healthy, ongoing pregnancy. At the same time, considering that bleeding and menstrual-like cramping are often the only symptoms, most women assume they are having their menstrual cycle. Bleeding after a positive pregnancy test can be also due to the implantation, spotting often appearing in 10-14 days after conception, as a brownish or pinkish discharge. The chemical pregnancy is not associated with pregnancy-related symptoms like fatigue or nausea $[1,2]$.
A chemical pregnancy doesn't usually need medical intervention or treatment. As soon as 2 weeks after an early pregnancy loss, most women can attempt to get pregnant again. A history of chemical pregnancy doesn't associate difficulties in conceiving again. On the contrary, it is a positive sign that a woman could obtain a pregnancy in the future [1].

A chemical pregnancy can also occur after in vitro fertilization (IVF) [2], having a chemical pregnancy is the first IVF cycle meaning that's more likely to have a successful pregnancy in a next IVF cycle [1].

Although there are not specific ways to prevent a chemical pregnancy [2], metformin can be used in pregnant women with polycystic ovary syndrome, being associated with a significant decreasing in the rates of early pregnancy loss [3]. In order to solve the inadequate secretion of progesterone, dydrogesterone was widely used in preventing the recurrent and the threatened miscarriage, but due to the high association with congenital heart disease, it is not used anymore in many countries now $[4,5]$.

\section{Risk factors for miscarriage}

Epidemiological factors

Recurrent spontaneous miscarriage is defined as three or more consecutive pregnancy losses before 24 weeks of gestation [5-8]. It affects 1-2\% of women of reproductive age trying to conceive $[6,8]$.

A strong independent risk factor for pregnancy loss is the maternal age at conception; the risk rising from $11 \%$ at $20-24$ years of age to $93 \%$ at 45 years of age. Another risk factor, but with a lower impact is the advanced paternal age (over 40 years of age). The risk of miscarriage 
increases after each successive pregnancy loss, from $9 \%$ after no losses, $12 \%$ after one, $20 \%$ after two and $40 \%$ after three or more pregnancy losses $[6,8]$. Other risk factors are: obesity, which is associated with early recurrent miscarriage, heavy alcohol consumption of 5 or more units per week, which leads to an increased risk of sporadic miscarriage, maternal cigarette smoking and high caffeine consumption of more than three cups of coffee per day, which have dose-dependent relationships with the risk of miscarriage $[6,8,9]$.

\section{Genetic factors}

Regarding the chromosomal disorders, the most important cause of miscarriage before ten weeks of pregnancy is the fetal aneuploidy. The cytogenetic abnormalities are described at least in $50-60 \%$ of all miscarriages, trisomy being the most frequent, with a risk of occurrence increasing with the maternal age. In 2-5\% of the recurrent miscarriages, one partner has a balanced structural chromosomal anomaly, which can be either a Robertsonian translocation, or a balanced reciprocal translocation [10]. Although theyare phenotypically normal, their meiosis consists in abnormal segregation, which leads to $50-70 \%$ of their gametes and embryos to be unbalanced [8], thus turning the pregnancy into miscarriage.

\section{Anatomical factors}

Between $1.8 \%$ and $37.6 \%$ of women presenting with recurrent miscarriage are having congenital uterine anomalies, such as bicornuate and septate uterus. Miscarriages occurring in the context of an uterine septum may be explained by the poor vascularization of fibromuscular tissue composing the septum, this leading to a bad development of the decidua and the placenta [11].

It is considered that uterine fibroids, which are affecting $30 \%$ of women at conceiving age, impede the embryonic implantation because of their space-occupying effect, which leads to a lower expression of HOX 10, a gene involved in implantation and differentiation $[6,8]$.

\section{Inherited thrombophilia}

Although inherited thrombophilia is associated more with second-trimester miscarriage, it can also increase the risk of recurrent miscarriage, the possible mechanism being the thrombosis of the uteroplacental circulation. This pathology includes protein S deficiency, activated protein $\mathrm{C}$ resistance, prothrombin gene mutation and factor $\mathrm{V}$ Leiden [8].

\section{Antiphospholipid syndrome}

Antiphospholipid syndrome is an acquired autoimmune disorder and one of the important treatable causes of recurrent miscarriage. It is characterized by antiphospholipid antibodies including anti-Beta-2glycoprotein 1 antibodies, lupus anticoagulant and anticardiolipin antibodies. Antiphospholipid antibodies appear in $15 \%$ of women with recurrent miscarriage, being responsible of a $90 \%$ risk of further pregnancy loss, in all cases left untreated. The mechanisms by which these antibodies lead to pregnancy morbidity are the inhibition of trophoblastic function and differentiation and placental injuries mediated by inflammation, as a response to the activated complement. Also, in later pregnancy, these antibodies are leading to thrombosis of the uteroplacental vessels $[6,8]$.

\section{Endometrial factors}

Some cases of recurrent miscarriage are explained by disorders of decidualisation, a phenomenon consisting in changes of the stroma, endometrial glands and cellular composition induced by progesterone, in order to support the implantation of the embryo. Based on the observation that the time of conception is significantly reduced in some women with recurrent miscarriage, it was developed a theory which suggests that the endometrium sometimes allows an abnormal development of the embryos, which will finally miscarry to implant. Another theory talks about an inadequate secretion of progesterone, either in early pregnancy or in the luteal phase of the menstrual cycle. This second theory revealed the critical importance of progesterone, which is essential for implantation of the embryo, inducing secretory changes in the endometrium $[8,12]$.

\section{Endocrine factors}

Maternal endocrine disorders such as diabetes mellitus and thyroid dysfunction have been associated with spontaneous miscarriage [6,8,13-15]. A risk factor for recurrent miscarriage is the poor controlled diabetes, with high levels of haemoglobin Alc during the first trimester of pregnancy. Also, the treated thyroid dysfunction doesn't increase the risk of spontaneous abortion. While the role of antithyroid antibodies in the occurrence of miscarriage remains unclear, hyperprolactinemia, which is linked with thyroid disorders, has also been associated with pregnancy loss. The risk of miscarriage is linked with polycystic ovary syndrome (PCOS), the mechanism probably being based on the insulin resistance, while the elevated free androgen index is also associated with an increased risk of subsequent miscarriage $[6,8]$.

\section{Infections}

A sporadic miscarriage can be the consequence of a severe infection with bacteremia or viremia, while the recurrent miscarriage may need an infective agent which can persist undetected in the genital tract $[16,17]$. For example, Chlamydia trachomatis leads to a persistent and asymptomatic infection, spreading to the endometrium or to the fetal tissue $[8,9]$.

\section{Immune factors}

Studies have found high levels of uterine Natural Killer (NK) cells associated with high rates of miscarriage, NK cells contributing to the cytokine response at the maternalfetal interface [7].

\section{Periconceptional caffeine intake}

Although several studies have shown no association between preconception caffeine intake and fetal loss [1820], there are others which have concluded that a high daily preconception caffeine consumption increases the risk of spontaneous abortion [18,21-23]. Another study has found that an intake of more than $300 \mathrm{mg}$ per day caffeine prior to pregnancy increased the risk of fetal loss by $31 \%$ [18].

\section{Alcohol intake}

The risk of spontaneous abortion is also linked with prenatal alcohol exposure, especially before or around the time of conception [18,24,25].

\section{Radiations}

Another harmful environmental factor in pregnant women is the radiation exposure, which increases the risk 
of early miscarriage. The study which found this correlation included mothers who were exposed to radiations in the workplace $[18,26]$.

\section{Medication related with spontaneous miscarriage Nonsteroidal anti-inflammatory drugs (NSAIDs)}

Nonsteroidal anti-inflammatory drugs are widely used by pregnant women, their periconception intake being correlated with an increased risk of miscarriage, that being a dose-response relationship [27-30]. The risk of miscarriage is increased by $80 \%$ in case of using NSAIDs during pregnancy, being much higher when this medication was used for longer than a week, or it was taken around conception [30,31].

The link between NSAIDs and the risk of miscarriage may be explained by the main pharmacologic effect of this drug class, which is the inhibition of the prostaglandin's production, finallyleading to malimplantation. A successful embryonic implantation depends on the prostaglandin's levels. Taking into account that the process of implantation is affected during early pregnancy, the risk was especially observed for early miscarriage $[30,32,33]$. This was also proven by the stronger association of miscarriage and women with a body mass index lower than $25 \mathrm{~kg} / \mathrm{m}^{2}$, this finding might be explained by the fact that obesity stimulates the prostaglandin biosynthesis, that being essential for the embryonic implantation [28]. It was observed that cyclo-oxygenase 2 inhibitors, which are the newer selective NSAIDs are leading to an increased risk of post-implantation and peri-implantation miscarriages, being classified as pregnancy category C [30].

Although NSAIDs and aspirin are increasing the risk of miscarriage, studies haven't shown the same effect for Paracetamol, which has a lot of the indications for use of NSAIDs. That can be explained by the different pharmacological effect of the Paracetamol $[30,34]$.

\section{Inhaled corticosteroids}

Corticosteroids are globally used by $2 \%$ of pregnant women in early pregnancy. Most studies have shown a correlation between the use of inhaled corticosteroids and a slightly increased risk of spontaneous abortion, the oral use doesn't associate the same risk [35].

Inhaled administration of corticosteroids is related only to early miscarriage, a correlation with the late miscarriage hasn't been described yet. This reflects that intrauterine exposure to this medication influences the fetal environment, leading to an increased risk of early pregnancy loss [35-37].

A common indication for inhaled corticosteroids is asthma, which is considered itself a risk factor for miscarriage. In addition, the risk of miscarriage is higher among women with history of one or more asthma exacerbations in the year before the pregnancy compared with those without exacerbations $[35,38,39]$. This fact can be explained by the abnormal smooth muscle activity of the uterus, which is induced by hypoxia during the asthma exacerbations $[35,40,41]$. So, it's difficult to separate the effect of inhaled corticosteroids from the effect of the underlying asthma [35].

Although oral route of administration for corticosteroids leads to increased degrees of fetal exposure because of their higher concentrations in the maternal circulation $[35,42]$; there are no reports of similar correlation with the risk of pregnancy loss as it was found for the inhaled medication [35]. Furthermore, it was showed that high doses of oral corticosteroids have a protective effect, thus they are used in preventing the recurrent miscarriages, although there are some disagreements about their effectiveness [35,40,43-45]. This may be explained by the anti-inflammatory properties of oral corticosteroids, which inhibitin high doses the abnormal immune response, which is frequently responsible for the miscarriages [35,41].

\section{Antiepileptic drugs}

Studying the risk of spontaneous abortions associated with maternal use of antiepileptic drugs (AEDs) has shown that the maternal exposure to AED polytherapy is one of the most important risk factor for intrauterine death among the pregnant women with epilepsy. Still, the strongest predictor of intrauterine death was the presence of major congenital malformations in at least one of the parents, suggesting that fetal loss is influenced more by intrinsec and genetic parental or maternal transplacental factors than by epilepsy or antiepileptic treatment [46].

There are numerous controversies about the role of the antiepileptic medication in spontaneous abortions, some studies showing a significantly increased risk of AEDs use among women without epilepsy and no association between spontaneous abortions and AEDs use during pregnancy in women with epilepsy [46,47].

A prospective study which has included 7055 pregnancies in women with epilepsy found that the risk of intrauterine death is significantly increased by some parameters. It was revealed that the risk is increased by maternal age, the older women being at a higher risk and by the number of previous pregnancies with intrauterine deaths, a greater risk corresponding to a greater number. It was also found a decreasing risk of pregnancy loss with increasing gestational week, the majority of miscarriages occurring in early pregnancy [46]. While some studies reported higher rates of pregnancy losses in women with localization-related epilepsy [46,48], this study has found an increased risk among the women with undetermined or unclassified epilepsy [46]. Comparing 7 different antiepileptic treatment categories including 6 monotherapies and a polytherapy, they found no relationship between occurrence of pregnancy loss and AED monotherapy, although this is the predominant treatment regimen among the pregnant women with epilepsy; this finding is consistent with other studies $[46,49-$ 52]. Another observation refers to the fact that it was no correlation between intrauterine death and the dose of antiepileptic drugs, at least for lamotrigine, carbamazepine and valproic acid. However, the polytherapy was associated with a significantly higher risk of pregnancy loss when compared with all monotherapies combined [46]. As regards the major convulsive seizures, these have no influence on spontaneous abortions [46,49].

Approaching the folate supplementation during pregnancy among the women with epilepsy, there are some disagreements. While some studies showed that periconceptional folate is related with a reduced rate of spontaneous abortion, others found no relationship between folate supplementation and intrauterine death $[46,53]$.

\section{Antidepressant medication}

Antidepressants use among pregnant women has increased in the last decades, the recent prevalence being between 3.2 and $7.6 \%$. The most common prescribed antidepressants are the selective serotonin reuptake inhibitors (SSRIs), which have been associated with an increased risk of miscarriage [54].

Although there are conflicting results of the studies regarding the association between antidepressants use and miscarriage, more recent studies showed a greater 
risk of spontaneous abortion related to the antidepressants use during the first trimester, when compared with unexposed women, with and without depression $[55,56]$. It was found a particularly higher risk for the serotonin and norepinephrine reuptake inhibitors monotherapy, but all classes of antidepressant have been associated with elevated risks of miscarriage [57].

Comparing the unexposed women diagnosed with depression in the previous 4 years with unexposed women without depression, it was revealed a slightly elevated risk of miscarriage for the previous ones, suggesting that depression itself is a risk factor for severe pregnancy outcomes, such as miscarriages [57].

Moreover, it was proven an elevated risk of miscarriage ranging from 1.5 to 1.7 among prenatal antidepressants users. A study including women who took antidepressants in the 3 months before pregnancy, but not in the first trimester, showed a lower relative risk of spontaneous abortion than first trimester antidepressants users. Also, it was showed that stopping antidepressants use before pregnancy leads to a decreased risk of miscarriage [57]. Another study based on the use of SSRIs found that continuing the antidepressant medication during the first trimester leads to a 20\% higher risk of miscarriage than stopping it [54].

The mechanism of miscarriage, suggested by some studies, is that antidepressants may increase the risk of pregnancy loss by acting directly on chromosomal or placental development [57-59].

\section{Antihypertensive drugs}

Chronic hypertension in pregnant women is associated with severe complications, such as: miscarriage or fetal death, placental abruption, eclampsia, preeclampsia, HELLP syndrome, liver or renal failure, intrauterine growth restriction and preterm birth [60-64]. In order to reduce the incidence of these adverse outcomes, the mild and moderate hypertension during pregnancy must be carefully treated and supervised, decreasing the risk of severe hypertension's occurrence [60].

The most used drugs for the treatment of hypertension are angiotensin-converting enzyme inhibitors (ACEIs) and angiotensin receptor blockers (ARBs), which are also used for the treatment of chronic kidney disease (CKD) and heart failure. Exposure to this medication in the second and third trimesters of pregnancy is known to be harmful for the fetus [65].

Studying the effect of ACEI and ARB exposure in early pregnancy proved that these classes of medication are associated with increased rates of miscarriages. The higher rate of spontaneous abortion was also observed for the other antihypertensives, showing a non-specific effect of the treatment in combination with the underlying disease [65-67].

Another risk factor for early miscarriage is the chronic kidney disease, which affects only 1 from 750 pregnancies, because of the reduced fertility rates $[26,65,68-70]$.

Artemisinin-based combination therapy (ACT) antimalarias

ACT is being used as a first-line treatment for falciparum malaria in the endemic countries, ACT exposure being more common than quinine exposure $[71,72]$. Because of the limited data regarding the safety of this therapy in pregnant women, treatment in the first trimester is not recommended unless oral quinine is not available or the life of the mother is at risk $[57,73,74]$.

Animal studies have found an increased rate of fetal loss based on the embryo-toxicity of artemisinin, which affects the primitive erythroblasts. In humans, these cells correspond to the primary form of red blood cells in circulation between 4 and 10 weeks of gestation $[57,75]$.

In addition, malaria itself can be responsible for severe outcome, such as fetal loss, perinatal mortality, preterm birth and even maternal death. A retrospective analysis showed that both symptomatic and asymptomatic malaria infection is an important risk factor for miscarriage. However, the same study found no relationship between the first trimester artemisinin exposure and pregnancy loss, while other studies revealed a higher risk of miscarriage among women treated with ACT in the first trimester compared with the unexposed women. Also, the risk associated with ACT was similar or lower compared to oral quinine $[57,76]$.

\section{Diclofenac/Misoprostol}

Misoprostol is a prostaglandin El analog usually used in combination with diclofenac in many rheumatic diseases and inflammatory disorders, in order to prevent gastric ulcer, which is an adverse effect of NSAID. It decreases the gastric acid secretion through its mechanism of reducing the proton pump activity. In addition, misoprostol stimulates the contraction of the smooth muscles of the uterus, being related with an increased risk of miscarriage. Itcan happen notonly directly, butalso indirectly, the uterine contractions leading to vascular disruption and a subsequent increased rate of malformations [57]. Because of this effect on the uterus, Misoprostol is administrated vaginally for medically induced abortions in doses of 400$800 \mathrm{mcg}$, in combination with Mifepristone or alternatively methotrexate $[57,73,77]$.

Studying the women exposed at diclofenac/ misoprostol three months prior pregnancy, it was found an increased risk of miscarriage in the early pregnancy, even though the medication was used in a lower dose than that recommended for induced abortion and in oral, notvaginal route [57].

Although combination diclofenac/misoprostol is contraindicated during pregnancy, it's important to consider that only $50 \%$ of pregnancies are planned, that leading to an increased risk of exposure during the early pregnancy $[57,78]$.

\section{Diseases related to spontaneous miscarriage}

Polycystic ovary syndrome (PCOS)

PCOS is one of the main causes of anovulatory infertility. Compared to the general population, this condition has been associated with higher rates of early pregnancy loss $(30-60 \%)[3,79,80]$. In addition, hyperinsulinemic resistance is considered an independentrisk factor for early miscarriage, having a bad influence on the implantation environment and on the endometrial function [3].

\section{Subclinical hypothyroidism}

This condition is defined by a normal level of serum free thyroxine and a raised level of serum thyroid-stimulating hormone, which is above the upper limit of normal (TSH > = $4.15 \mathrm{mU} / \mathrm{l})$. Although there are studies which demonstrated a correlation between an increased risk of miscarriage and subclinical hypothyroidism, others have shown no significant difference in loss rate between euthyroid women and women with subclinical hypothyroidism [8184].

\section{Rheumatoid arthritis}

Recent studies have observed a significantly higher risk of both early and late spontaneous abortion among women 
with rheumatoid arthritis, compared to the general population. It was found that women with rheumatoid arthritis experience more often recurrent events of early miscarriage. This can also be explained by the effect of methotrexate, an antirheumatic treatment, which was itself associated with an increased risk of spontaneous abortion. So, it's very important to establish if pregnancies occurred under disease-modifying antirheumatic drugs such as methotrexate, those being used around the time of conception [85].

\section{Zika Virus Infection}

Another condition which has been associated with miscarriage is Zika Virus infection. Although this correlation wasn't studied enough until now, some cases were described in the literature [86-88].

A recent article reported the case of a 10 weeks pregnant woman, which visited an outpatient clinic because of headache, mild arthralgies and a pruritic, macular rash. These symptoms had begun the day after her return from a trip to Suriname, where she didn't use personal protective measures or malaria chemoprophylaxis. Although her symptoms resolved spontaneously after 6 days, the ultrasonography performed on day 14 after the onset of symptoms revealed no fetal heartbeat, at an estimated gestational age of 11 weeks and 4 days. 21 days after the onset of the symptoms, it was performed amniocentesis, followed by dilatation and curettage. Testing the amniotic fluid, the fetal and the placental tissue, a positive result for Zika Virus was obtained. Furthermore, the histopathological analysis of the placental tissue specimens revealed that the intrauterine fetal death occurred one week before the curettage. Using in situ hybridization, evidence of Zika Virus infection was proven in fetal mesenchymal cells, particularly in the perichondrium and also in the amniotic epithelial cells [86]. This finding leads to the observation that Zika Virus replicates in pluripotent cells (amniotic cells), which are important for the early-stage embryo development; that may be a possible explanation for the association of the Zika Virus infection with the miscarriage [86].

Another essential finding was the prolonged viremia of the patient, until the day 21 from the onset of the symptoms, which is not corresponding with the current assumption that Zika Virus viremia can be detected only in the first 7 days from the onset of the symptoms $[86,89]$.

\section{Conclusions}

Between 50 and $75 \%$ of all miscarriages are chemical pregnancies, which are early pregnancy losses occurring shortly after implantation. Although the gestational sac isn't visible on ultrasounds and the pregnancy-related symptoms are not present yet, the chemical pregnancy can be early detected by a positive pregnancy test. The chemical pregnancy doesn't usually need treatment and in many cases there are no specific ways to prevent it, but taking to consideration all the causes proved to be involved in early miscarriage, eliminating the risk factors frequently turns into favorable outcomes. Every practitioner should have in mind that whenever women have a personal history of early miscarriage, a close and careful look at the health state and environmental details is capable to change for the future the bad prognosis into a favorable one.

\section{References}

1. NALL, R. Medical News Today. Retrieved from https://www.medicalnewstoday.com/articles/322678.php, 2018. 2.HIGUERA, V. (2017, June, 26). Retrieved from https://www.he althline.com/health/pregnancy/chemical-pregnancy

REV.CHIM.(Bucharest) 70 No. 11 \2019

http://www.revistadechimie.ro
3.AL-BIATE, M. A. Taiwan J. Obstet. Gynecol., 54, no. 3, 2015, p. 266. 4.ZAQOUT, M., ASLEM, E., ABUQAMAR, M., ABUGHAZZA, O., PANZER, J., DE WOLF, D. Pediatr. Cardiol., 36, no. 7, 2015, p.1483

5.MIRZA, F. G., PATKI, A., PEXMAN-FIETH, C. Gynecol. Endocrinol., 32, no. 2, 2016, p. 97.

6.DIEJ OMAOH, M. F. Med. Princ. Pract., 24, no. 1, 2015, p. 38.

7.VEDUTA, A., PETCA, R., PETCA, A. Proceedings Of The 14th National Congress Of Urogynecology And The National Conference Of The Romanian Association For The Study Of Pain, Eforie, Romania, 2017, p. 199.

8.CHETTY, M., DUNCAN, C. W. Obstet, Gynaecol, Reprod, Med, 25, no. 2, 2014, p. 31.

9.MEHEDINTU, C., BRATILA, E., CIRSTOIU, M., PETCA, A., BRINDUSE, L. A., et al. Rev. Chim.(Bucharest), 70, no. 7, 2019, p. 2375.

10.ZVANCA, M. E., PETCA, A., BOT, M. Rev. Rom. Med. Lab., 22, no. 4, 2014, p. 515.

11.RUSU, M. C., POP, F., HOSTIUC, S., MANTA, L., MARU, N., GRIGORIU, M. Rom. J. Morphol. Embryol., 59, no. 3, 2018, p. 663.

12.PETCA, A., VLADAREANU, S., RADU, D. C., BOT, M., BERCEANU, C., et al. Rom. J. Morphol. Embryol., 58, no. 2, 2017, p. 619.

13.J AUNIAUX, E., FARQUHARSON, R. G., CHRISTIANSEN, O. B., \& EXALTO, N. Hum. Reprod., 21, no. 9, 2006, p. 2216.

14.CHRISTIANSEN, O. B., NYBO ANDERSON, A. M., BOSCH, E. Fertil. Steril., 83, 2005, p. 821.

$15{ }^{* * *}$ NO, G. T. G. The investigation and treatment of couples with recurrent first-trimester and second-trimester miscarriage. GreenTop Guideline No. 17. London, RCOG Press 2011.

16.PETCA, A., RADU, D. C., PETCA, R. C., MEHEDINTU, C., BARAC, R. I., et al. Rev. Chim.(Bucharest), 70, no. 6, 2019, p. 2021.

17.ZAHA, D. C., BUNGAU, S., ALEYA, S., TIT, D. M., VESA, C. M., et al. Sci. Total Environ. 687, 2019, p. 118.

18.LASSI, Z. S., IMAM, A. M., DEAN, S. V., BHUTTA, Z. A. Reprod. Health, 11, no. 3, 2014, S6.

19.GADSBY, R., BARNIE-ADSHEAD, A. M., JAGGER, C. Br. J. Gen. Pract., 43, no. 371, 1993, p. 245.

20.LAWSON, C. C., LEMASTERS, G. K., WILSON, K. A. Reprod. Toxicol., 18, no. 5, 2004, p. 625.

21.TOLSTRUP, J. S., KJAER, S. K., MUNK, C., MADSEN, L. B., OTTESEN, B., BERGHOLT, T., GRONBAEK, M. Human. Reprod., 18, no. 12, 2003, p. 2704

22.AXELSSON, G., RYLANDER, R., MOLIN, I. (1989). Occup. Environ. Med., 46, no. 6, 1989, p. 393.

23.FENSTER, L., HUBBARD, A. E., SWAN, S. H., WINDHAM, G. C., WALLER, K., HIATT, R. A., BENOWITZ, N. Epidemiology, 8, no. 5, 1997, p. 515.

24.WINDHAM, G. C., VON BEHREN, J., FENSTER, L., SCHAEFER, C., SWAN, S. H. Epidemiology, 8, no. 5, 1997, p. 509.

25.KESMODEL, U., WISBORG, K., OLSEN, S. F., HENRIKSEN, T. B., SECHER, N. J. Am. J. Epidemiol., 155, no. 4, 2002, p. 305.

26.PETCA, R. C., POPESCU, R. I., MEHEDINTU, C., BOT, M., VEDUTA, A., PETCA A. Proceedings of The 6th Congress Of The Ultrasound Society In Obstetrics And Gynecology / 34th Fetus As A Patient International Congress, Bucharest, 2018, p. 478.

27.ERICSON, A., KALLEN, B. A. Reprod. Toxicol., 15, no. 4, 2001, p. 371.

28.LI, D. K., FERBER, J. R., ODOULI, R., QUESENBERRY, C. Am. J. Obstet. Gynecol., 219, no.3, 2018, p. 275-e1.

29.NIELSEN, G. L., SORENSEN, H. T., LARSEN, H., PEDERSEN, L. BMJ, 322, 2001, p.266.

30.LI, D. K., LIU, L., ODOULI, R. BMJ, 327, no.7411, 2003, p. 368. 31.ZVANCA, M. E., BOT, M., RADU, D., RADU, N., PETCA, A. J. Matern. Fetal Neonatal. Med., 32, no. 4, 2019, p. 604.

32.KACZYNSKI, P., KOWALEWSKI, M. P., WACLAWIK, A. Reproduction, 151, no. 5, 2016, p. 539.

33.VAN DER WEIDEN, R. M., WOUTERS, J. M. (1997). Br. J. Rheumatol., 36, no. 5, 1997, p. 605.

34.RADULESCU, A., MADAN, V., AUNGURENCI, A., BRATU, O., FARCAS, C., et al. Rom. J. Mil. Med., 118, no. 3, p. 20. 
35.BJ ORN, A. M. B., EHRENSTEIN, V., NOHR, E. A., NORGAARD, M. (2015). Basic Clin. Pharmacol. Toxicol., 116, no. 4, 2015, p. 308. 36.ZGURA, A., GALES, L., HAINEALA, A. B., BRATILA, E., MEHEDINTU, C., et al. Rev. Chim.(Bucharest), 70, no. 7, 2019, p. 2362.

37.BJORN, A. M. B., NIELSEN, R., NORGAARD, M., NOHR, E. A., EHRENSTEIN, V. Clin. Epidemiol., 5, 2013, p. 287.

38.SCHATZ, M., ZEIGER, R. S., HARDEN, K., HOFFMAN, C. C., CHILINGAR, L., PETITTI, D. J. Allergy Clin. Immunol., 100, no. 3, 1997, p. 301.

39.TATA, L. J., LEWIS, S. A., MCKEEVER, T. M., SMITH, C. J., DOYLE, P., SMEETH, L., HUBBARD, R. B. Am. J. Respir. Crit. Care Med., 175, no. 10, 2007, p. 991.

40.LASKIN, C. A., BOMBARDIER, C., HANNAH, M. E., MANDEL, F. P., RITCHIE, J. W., FARWELL, V. N. Engl. J. Med., 337, 1997, p. 148. 41.MELLOR. A., MUNN, D. Annu. Rev. Immunol., 18, 2000, p. 367. 42.CHROUSOS, G. P., MARGIORIS, A. N. Basic Clin. Pharmacol., 9, 2007, p. 635.

43.PORTER, T. F., LACOURSIERE, Y., SCOTT, J. R. Cochrane Database Syst. Rev., 19, 2006

44.SPINU, D., BRATU, O., POPESCU, R., MARCU, D., RADULESCU, A., MISCHIANU, D. Rom. J. Mil. Med., 118, no. 3, p. 12.

45.SALMON, J. E. J. Clin. Invest, 114, 2004, p. 15.

46.TOMSON, T., BATTINO, D., BONIZZONI, E., CRAIG, J. J., LINDHOUT, D., PERUCCA, E. Neurology, 85, no. 7, 2015, p. 580.

47.BECH, B. H., KJ AERSGAARD, M. I. S., PEDERSEN, H. S., HOWARDS, P. P., SØRENSEN, M. J., OLSEN, J., CHRISTENSEN, J. BMJ , 349, 2014, g5159.

48.SCHUPF, N., OTTMAN, R. Epilepsia, 38, 1997, p. 824.

49.ANNEGERS, J. F., BAUMGARTNER, K. B., HAUSER, W. A., KURLAND, L. T. Epilepsia, 29, 1988, p. 451.

50.TOMSON, T., BATTINO, D., BONIZZONI, E. Lancet Neurol., 10, 2011, p. 609.

51.HERNANDEZ-DIAZ, S., SMITH, C. R., SHEN, A. Neurology, 78, 2012, p. 1692.

52.CAMPBELL, E., KENNEDY, F., RUSSELL, A. J. Neurol. Neurosurg. Psychiatry 85, 2014, p. 1029.

53.PITTSCHIELER, S., BREZINKA, C., JAHN, B., TRINKA, E., UNTERBERGER, I., DOBESBERGER, J., LUEF, G. J. Neurol., 255, no.12, 2008, p. 1926.

54.J OHANSEN, R. L. R., MORTENSEN, L. H., ANDERSEN, A. M. N., HANSEN, A. V., STRANDBERG LARSEN, K. Paediatr. Perinat. Epidemiol., 29, no. 1, 2015, p. 72.

55.ALMEIDA, N. D., BASSO, O., ABRAHAMOWICZ, M., GAGNON, R., TAMBLYN, R. Epidemiology, 27, no. 4, 2016, p. 538.

56.CHISOLM, M. S., PAYNE, J. L. BMJ, 352, 2016, h5918.

57.ANDERSEN, J. T., MASTROGIANNIS, D., ANDERSEN, N. L., PETERSEN, M., BROEDBAEK, K., CEJVANOVIC, V., JIMENEZ-SOLEM, E. Arch. Gynecol. Obstet., 294, no. 2, 2016, p. 245.

58.LOHSE, S. R., FARKAS, D. K., LOHSE, N., SKOUBY, S. O., NIELSEN, F. E., LASH, T. L., EHRENSTEIN, V. Clin. Epidemiol., 2, 2010, p. 247. 59.PETCA, A., PETCA, R. C., ZVANCA, M., MARU, N., MASTALIER, B., DOGAROIU, C. Rom. J. Leg. Med, 27, no. 1, 2019, p. 43.

60.LENNESTAL, R., OLAUSSON, P. O., KALLEN, B. Eur. J. Clin. Pharmacol., 65, no. 6, 2009, p. 615.

61.REY, E., COUTURIER, A. Am. J. Obst. Gynecol. 181, 1994, p. 410. 62.MCCOWAN, L. M., BUIST, R. G., NORTH, R. A., GAMBLE, G. Br. J. Obstet. Gynecol., 103, no. 2, 1996, p. 123.
63.SIBAI, B. M., CARITIS, S. N., HAUTH, J. C., MACPHERSON, C., VANDORSTEN, J. P., KLEBANOFF, M., DOMBROWSKI, M. P. Am. J. Obst. Gynecol., 183, no. 6, 2000, p. 1520.

64.RAY, J. G., BURROWS, R. F., BURROWS, E. Early. Hum. Dev. 64, 2001, p. 129.

65.PUCCI, M., SARWEEN, N., KNOX, E., LIPKIN, G., MARTIN, U. Expert Rev. Clin. Pharmacol., 8, no. 2, 2015, p. 221.

66.DIAV-CITRIN, O., SHECHTMAN, S., HALBERSTADT, Y., FINKELPEKARSKY, V., WAJNBERG, R., ARNON, J., ORNOY, A. Reprod. Toxicol., 31, no. 4, 2011, p. 540.

67.KARTHIKEYAN, V. J., FERNER, R. E., BAGHDADI, S., LANE, D. A., LIP, G. Y., BEEVERS, D. G. J. Hypertens., 29, no. 2, 2011, p. 396.

68.WILLIAMS, D., DAVISON, J. BMJ , 336, no. 7637, 2008, p. 211.

69.J ONES, D. C., HAYSLETT, J. P. N. Engl. J. Med., 335, no. 4, 1996, p. 226.

70.VELLANKI, K. Adv. Chronic Kidney Dis., 20, no. 3, 2013, p. 223.

71.DELLICOUR, S., DESAI, M., AOL, G., ONEKO, M., OUMA, P., BIGOGO, G., FEIKIN, D. (2015). Malar. J., 14, no. 1, 2015, p. 461.

72.*** W HO. World Malaria Report: 2013. Geneva: World Health Organization 2013.

73.EL-REFAEY, H., RAJASEKAR, D., ABDALLA, M., CALDER, L., TEMPLETON, A. N. Engl. J. Med., 332, no. 15, 1995, p. 983.

74.KNUDSEN, L. B., OLSEN, J. Dan. Med. Bull., 45, no. 3, 1998, p. 320. 75.TANHA, F. D., GOLGACHI, T., NIROOMAND, N., GHAJARZADEH, M., NASR, R. Arch. Gynecol. Obstet., 287, no.1, 2013, p. 65.

76.VAUZELLE, C., BEGHIN, D., COURNOT, M. P., ELEFANT, E. Reprod. Toxicol., 36, 2013, p. 98.

77.TANG, J., KAPP, N., DRAGOMAN, M., DE SOUZA, J. P. Int. J. Gynaecol. Obstet., 121, no. 2, 2013, p. 186.

78.SHEPARD, T. H. The Lancet, 346, 1995, p.780.

79.BALEN, A. H., TAN, S. L., MACDOUGALL, J., JACOBS, H. S. Hum. Reprod., 8, no.6, 1993, p. 959.

80.SAGLE, M., BISHOP, K., RIDLEY, N., ALEXANDER, F. M., MICHEL, M., BONNEY, R. C., FRANKS, S. BMJ , 297, no. 6655, 1988, p. 1027. 81.VAN DIJK, M. M., VISSENBERG, R., BISSCHOP, P. H., DAWOOD, F., VAN WELY, M., GODDIJ N, M., FARQUHARSON, R. G. Reprod. Biomed. Soc. Online, 33, no. 6, 2016, p. 745.

82.BENHADI, N., WIERSINGA, W. M., REITSMA, J. B., VRIJ KOTTE, T. G. M., BONSEL, G. J. Eur. J. Endocrinol., 160, no. 6, 2009, p. 985.

83.LIU, H., SHAN, Z., LI, C., MAO, J., XIE, X., WANG, W., WANG, X. Thyroid, 24, no. 11, 2014, p. 1642.

84.CLEARY-GOLDMAN, J., MALONE, F. D., LAMBERT-MESSERLIAN, G., SULLIVAN, L., CANICK, J., PORTER, T. F., D'ALTON, M. E. Obstet. Gynecol., 112, no.1, 2008, p.85.

85.WALLENIUS, M., SALVESEN, K. Å., DALTVEIT, A. K., SKOMSVOLL, J. F. J Rheumatol., 42, no. 9, 2015, p. 1570.

86.VAN DER EIJK, A. A., VAN GENDEREN, P. J., VERDIJK, R. M., REUSKEN, C. B., MÖGLING, R., VAN KAMPEN, J. J., RAJ, V. S. N. Engl. J. Med., 375, no. 10, 2016, p. 1002.

87.SARNO, M., SACRAMENTO, G. A., KHOURI, R., DO ROSÁRIO, M. S., COSTA, F., ARCHANJ O, G., DE ALMEIDA, A. R. PLoS Negl. Trop. Dis., 10, no. 2, 2016, e0004517.

88.MARTINES, R. B. Morb. Mortal. W kly. Rep., 65, 2016, p. 159. 89.DRIGGERS, R. W., HO, C. Y., KORHONEN, E. M., KUIVANEN, S., JÄÄSKELÄINEN, A. J., SMURA, T., TIMOFEEV, J. N. Engl. J. Med., 374, no. 22, 2016, p. 2142.

Manuscript received: 23.09 .2019 